\title{
A NEW SOUTH AMERICAN GENUS OF CONOPINAE.
}

BY s. W. WILLISTON, NEW HAVEN, CONN.

Hitherto but a single genus (Conops) of this group has received general acceptance among dipterologists. A second genus, Physocephala, was based by Schiner on characters in themselves of but little importance, and which I did not deem sufficient to separate our species in the first paper I published* on the North American forms. A further study, however, convinced me that they were sufficiently constant to warrant their use, particularly in connection with other important ones in the neuration, which I pointed out. $\dagger \quad$ I have recently had the opportunity of studying sixteen South American species of the two genera, collected by Mr. Herbert H. Smith, and I am yet more convinced of the validity of Physocephala as a genus.

A half dozen genera that Rondani attempted to establish (to say nothing of Lioy's fanciful productions) were based upon such confessedly trivial characters that they have no where commanded any attention by entomologists, save by Rondani's devoted follower, Mr. Bigot, who, in his last paper $\$$ on this family, while rejecting Physocephala, accepts Brachyglossum Rond., based upon the comparative lengths of the proboscis. I do not think Mr. Bigot's views will receive the approbation of many dipterologists.

The only other genus which presents any claims for acceptance is Pleurocerina Macq., which I suspect was based upon an accidental malformation, the more so as I have seen several specimens of Conops and Zodion with a very similar projection of the front, springing from the frontal lunule, and due to some artificial cause. I am not aware that the type species, described from Tasmania, has been recognized since its original description, and I think the genus had better be held in abeyance till specimens are again examined.

The sub-family Conopinae, then, consists of two genera, to which I here add the third, distinguished from the closely allied Conops by excellent structural characters.

"Trans. Conn. Acal., iv, 327.

† Ibic., vi., 388 .

† Ann. Soc. Ent. Fr., 1887, 31 . 


\section{Tropidomyia, gen. nov.}

Face, in profile, vertical and straight, with a median sharp ridge, on the sides plane or gently concave, wholly without grooves or lateral ridges. In front view, the face shows, below, a sharp triangular notch, rising a little above the lower border of the eyes, from the apex of which the sharp carina runs to the base of the antennæ. Wings narrow; anterior cross-vein near middle of discal cell, and opposite the termination of the auxiliary vein; termination of second vein remote from that of the first, the interval as great as that between the terminations of the second and third veins.

The above are the most essential characters, readily distinguishing this genus from Conops. Other characters that may or may not be of generic value are the following: Third joint of antennæe very short, scarcely longer than wide, shorter than the first, the latter about one-third or twofifths the length of the second. Posterior cross-vein straight, and rectangular to both the fourth and the fifth veins. Second segment of the abdomen in the male very slender, somewhat broader in front, nearly as long as the three following segments together; in the female the second segment is cylndrical, but less slender than in the male, only a little longer than the third, the sixth segment as long as the three preceding together, the fifth with a large process below. Proboscis as long as the hind femora. 'The legs and front, and general structure otherwise, are like those of Conops, sens. str.; the wings with their narrow cells present a very different appearance, however. The carinate, non-grooved structure of the face differs from that of all the other genera of Conopidae save Stylogaster, a species of which (S. stylatus Fabr., which is distinct from both the North American species) was found in the same region with the present species.

\section{'Tropidomyia bimaculata, n. sp.}

$\delta$, + . Face with a silvery, or slightly yellowish, sheen, showing the black ground-color in different reflections; a slender median black line on the carina. Vertical callosity yellowish red below, obscurely blackish and luteous, save the narrow margins, which are more yellow; close to the eyes below, a circular opaque black spot. Antennae brownish red, the third joint red; style short, conical, but little longer than the lateral projection. Thorax opaque black, thinly pollinose on the sides, a slender 
golden pollinose spot on the inner side of the humeri; humeri and scutellum red; disk of metanotum shining. Abdomen black, the second segment brownish red; sixth segment thickly whitish pollinose; fourth and fifth segments (fifth only in female?) with a narrow yellow hind margin. Legs blackish red; tibiae more red, tarsi black; a silvery spot on the outer distal part of the four anterior tibiae. Wings sub-hyaline, brownish in front, but without a distinct picture. Length $7,8 \mathrm{~mm}$.

Two males and one female, Chapada (near Cuyaba), Brazil (H. H. Smith). The yellow, intra-humeral spot and posterior abdominal margins appear to be wanting in one of the males.

\section{THREE SPECIES OF MOTHS NEW TO OUR FAUNA.}

BY HENRY EDWARDS, NEW YORK.

After all, the geographical range of our fauna, as regards the distribution of insects, is but incompletely marked, and the fact that artificial lines cannot limit the habitat of a species is every day made more apparent. The Florida coast is constantly turning up species properly belonging to the fauna of the West Indies, and Texas and Arizona are as often adding Mexican forms to our list. It is, nevertheless, somewhat strange that three such conspicuous species as those hereafter noted should have only recently appeared within our limits, or at least for so long a time have escaped the watchful eyes of our numerous observers. They may all be cited as examples of the Mexican fauna, though Pseudosphinx Tetrio is also found in the $W$. Indies, and on the continent reaches as far south as the Argentine Confederation. As the insects are probably not known to our local collectors, I have thought it advisable to append descriptions of each.

FAM. SPHINGIDÆ.

Pseudosphinx Tetrio, Linn.

Whole upper surface light gray, the lines and markings brownish black. The basal half line is whitish, with a black dash behind it obliquely. Between it and the median line are some waved brownish indistinct streaks, reaching only from the costa to the middle of the wing. There is a very prominently marked discal spot, and a sub-triangular brown 